\title{
Improving Sweetpotato Starch Digestibility for Animal Feeding
}

\author{
Dapeng Zhang, Wanda W. Collins', and Suzanne Belding \\ Department of Horticultural Science, Box 7609, North Carolina State \\ University, Raleigh, NC 27695-7609
}

Additional index words. Ipomoea batatas, animal feed

\begin{abstract}
Eight sweetpotato [Ipomoea batatas (L.) Lam.] clones were evaluated for the digestibility of their starch in animals with a simple in vitro screening method. Starch digestibility varied significantly among clones. After dry-heat treatment at $100 \mathrm{C}$ for 30 minutes, digestibility of the most heat-sensitive clone increased only $37.8 \%$. Excellent repeatable results were obtained with a simple weight-loss method. This assay procedure can be used as a screening method in breeding digestible sweetpotatoes for animal feed.
\end{abstract}

Sweetpotato is an important animal feed in many developing countries. Leaves and storage roots can be used as feed in various forms. Annually, $\approx 20 \%$ to $30 \%$ of all sweetpotatoes produced in the world is consumed as animal feed (Lu et al., 1989; Woolfe, 1992). In many cases, however, the energy value of uncooked sweetpotato roots or dried chips, even on a dry-weight basis, did not equal that of corn, the most common feed ingredient. Substituting more than a moderate level of the corn diet with sweetpotato often decreased livestock weight gain and feeding efficiency (Woolfe, 1992). Poor starch digestibility was one of the mainconstraints. Generally, sweetpotato starch is less susceptible to enzyme hydrolysis than uncooked cereal starches (Dreher et al., 1984; Tsou and Hong, 1989). Sweetpotatoes usually need to be precooked to improve feeding efficiency (Tsou and Hong, 1989). Microwave cooking dried sweetpotato chips at 80 to $90 \mathrm{C}$ for up to $4.5 \mathrm{~min}$ did not change starch digestibility. Heating meal with dry air at 390C for $1 \mathrm{~min}$ increased starch digestibility by only $7 \%$. Performance of pigs eating heated meal was no better than that of pigs eating nonheated chips (Yeh and Bouwkamp, 1985). Popping chips at 6 to $8 \mathrm{~kg} \cdot \mathrm{cm}^{-2}$ pressure at 164 to $175 \mathrm{C}$ could improve starch digestibility as much as 194\% (Yeh et al., 1978), but this method has never been used commercially because it is not economically feasible (Woolfe, 1992). The possibility of breeding sweetpotato varieties with digestible starch has been suggested (Yeh and Bouwkamp, 1985). Rat feeding experiments in Taiwan and in vitro screening methods have shown that varieties differ significantly in the digestibility of their starch and the effects of these differences on protein digest-

\footnotetext{
Received for publication 21 Aug. 1992. Accepted for publication 5 Dec. 1992. This research was supported in part by the International Potato Center, Lima, Peru. The cost of publishing this paper was defrayed in part by the payment of page charges. Under postal regulations, this paper therefore must be hereby marked advertisement solely to indicate this fact.

'Graduate Research Assistant.

${ }^{2}$ Professor.

${ }^{3}$ Laboratory Research Analyst.
}

ibility. The amount of $\mathrm{CO}_{2}$ produced by pancreatin digestion followed by yeast fermentation determined starch digestibility (Tsou and Hong, 1989). Season also affected starch digestibility significantly. Storage roots harvested in the wet season were more resistant to pancreatin enzyme digestion than roots harvested in the dry season (Tsou and Hong, 1989). Gates and Sandstedt (1953) developed a simple gravimetric method for determining in vitro raw starch digestion. Starch was digested by bacterial a-amylase, and the resulting weight loss indicated the starch digestibility of various plant species. The objectives of this study were to 1) investigate starch digestibility variation among clones of a high drymatter sweetpotato population in North Carolina; 2) test the effect of dry-heat treatment on starch digestibility; and 3) test a simple in vitro screening method for breeding purposes.

Eight clones of a high dry-matter population were used in this experiment. Thirty plants of each clone were arranged in three replications ( 10 plants per plot) and grown in the field in a randomized complete-block design. The plants were grown for 110 days following standard cultural practices (Wilson et al., 1980).

Four freshly harvested U.S. no. 1 roots from each plot were washed, shredded, and mixed, and a 100-g sample was taken. Samples were frozen and subsequently freeze-dried. The dried samples were ground with a blender for $30 \mathrm{sec}$ so that they would pass through a 425- $\mu \mathrm{m}$ sieve (35-mesh) screen. The resulting powder was used as flour in subsequent assays. To extract raw starch, $200 \mathrm{~g}$ of fresh tissue was ground with $500 \mathrm{ml}$ distilled water in a blender for $3 \mathrm{~min}$. The ground mixture then was sieved and washed three times with distilled water and dried at $45 \mathrm{C}$ in a forced-air oven.

A modified Gates and Sandstedt (1953) method was used to assay starch digestibility. Fifteen milliliters of $0.15 \mathrm{M}$ phosphate buffer (pH 6.5) and $30 \mathrm{mg}$ pancreatin (activity at least equivalent to U.S. Pharmacopeia specification; Sigma Co., St. Louis) were added to 0.4 $\mathrm{g}$ raw starch (or flour) in $25-\times 150$-mm test tubes. The tubes were placed in a shaking waterbath and incubated at 30C. Shaking was adjusted to keep starch suspended. After $10 \mathrm{~h}$ of digestion, $5 \mathrm{ml} 1.0 \%$ sulfuric acid solution was added to stop enzymatic hydrolysis. Samples were centrifuged at $20,000 \times g$ for 5 $\mathrm{min}$; the resulting pellet containing the undigested starch or flour residue was washed with $15 \mathrm{ml} \mathrm{80 \%}$ ethanol and centrifuged again under the same conditions. The residue then was dried at $80 \mathrm{C}$ in a forced-air oven to a constant weight. Corn and potato starch (Sigma Co.) were used in each test as a control. A blank (without enzymatic hydrolysis) was included for each sample to correct for original soluble sugar in samples. Starch digestibility was expressed as a digestion index, which was the percent weight loss relative to corn starch or cornmeal (from a local food store) after pancreatin digestion. As a check on the weightloss method of determining the amount of starch digested, after being centrifuged, the supernatant was analyzed for total soluble sugar by the phenol-sulfuric acid method (Hodge and Hofreiter, 1972). The amount of carbohydrates reduced was calculated as milligrams of glucose equivalent.

The effect of dry heat on starch digestibility was tested by placing 0.4-g starch samples at $100 \mathrm{C}$ for 15 or $30 \mathrm{~min}$ followed by the digestibility assay described above. Four out of the eight clones were selected for this test (two clones with good and two with poor digestibility). Three treatments (blank, and $100 \mathrm{C}$ for 15 or $30 \mathrm{~min}$ ) with two replications were used for this test.

SAS Institute's analysis of variance and general linear model procedures were performed on the experimental data. For the field data, Duncan's multiple range test was used to compare clones. Means were compared at $P \leq$ 0.05 . The dry-heat treatment experiment was analyzed as a 4 (clone) $\times 3$ (heat) factorial design with two replications. Clone was the random factor and heating time was the fixed factor.

Starch digestibility varied significantly among the eight clones tested. The digestion index ranged from 29.4 to 76.8 in the starch sample and 34.2 to 98.9 in the flour samples (Table 1). Clone A-205 flour had a digestion index similar to cornmeal and significantly

Table 1. Starch digestion index for eight sweetpotato clones.

\begin{tabular}{|c|c|c|c|}
\hline \multirow[b]{2}{*}{ Clones } & \multicolumn{2}{|c|}{ Digestion index $^{2}$} & \multirow{2}{*}{$\begin{array}{c}\text { Glucose }^{y} \\
\text { (mg) }\end{array}$} \\
\hline & Starch & Flour & \\
\hline A-205 & $76.8 \mathrm{a}^{x}$ & $98.9 \mathrm{a}$ & $\overline{121 \mathrm{a}}$ \\
\hline A-18 & $60.1 \mathrm{~b}$ & $73.6 \mathrm{~b}$ & $106 \mathrm{~b}$ \\
\hline 1530 & $52.3 \mathrm{bc}$ & $55.7 \mathrm{c}$ & $100 \mathrm{c}$ \\
\hline 1719 & $45.8 \mathrm{~cd}$ & $46.4 \mathrm{~cd}$ & $96.9 \mathrm{~cd}$ \\
\hline A-159 & $40.0 \mathrm{c}-\mathrm{e}$ & $42.4 \mathrm{~cd}$ & $85.1 \mathrm{~d}$ \\
\hline 1870 & $37.6 \mathrm{de}$ & $41.5 \mathrm{~cd}$ & $83.7 \mathrm{e}$ \\
\hline 1582 & $34.8 \mathrm{de}$ & $41.3 \mathrm{~cd}$ & 81.9 ef \\
\hline A-144 & $29.4 \mathrm{e}$ & $34.1 \mathrm{~d}$ & $79.8 \mathrm{f}$ \\
\hline Corn & 100 & 100 & \\
\hline Potato & 24.43 & & \\
\hline
\end{tabular}

${ }^{\mathrm{x}}$ Digestion index $=$ (weight loss in sample/weight loss in corn starch) $\times 100$

'Glucose (mg) is the digested carbohydrate measured by the phenol-sulfuric acid method expressed as milligrams of glucose equivalence.

'Mean separation within columns by Duncan's multiple range test, $P \leq 0.05$. 
Table 2. Analysis of variance for the effect of dry heat on starch digestibility of four sweetpotato clones.

\begin{tabular}{lrrrr}
\hline Source of & & & & \\
variation & df & \multicolumn{1}{c}{ MS } & \multicolumn{1}{c}{ F } & $P$ \\
\hline Heating & 2 & 108.85 & 4.54 & 0.0632 \\
Clone & 3 & 2270.30 & 344.69 & 0.0001 \\
Heating & & & & \\
$\quad \times$ clone & 6 & 23.98 & 3.64 & 0.0276 \\
Error & 12 & 6.59 & & \\
\hline
\end{tabular}

higher than the other clones. Clone A-144 starch had the lowest digestion index, which was similar to that of potato starch. The high digestibility found in corn starch and cornmeal in contrast with the low digestibility in potato starch agrees with previous reports that cereal starch is most susceptible to a-amylase, potato starch is resistant, and sweetpotato starch is intermediately susceptible (Dreher, 1984). This result also agrees with Tsou and Hong's report (1989) that starch digestibility was significantly different among sweetpotato cultivars. The variation among sweetpotato clones suggests that sweetpotato starch digestibility may be improved by conventional breeding methods.

When sweetpotato flour was used as the sample, the relative rank of starch digestibility was the same as with the raw starch sample. Thus, the problem of starch digestibility in sweetpotato possibly is due to the physical or chemical properties of starch, rather than some nonstarch components such as a-amylase inhibitors, as is the case with legumes (Dreher et al., 1984).

Dry-heat treatment did not improve starch digestibility satisfactorily in any of the four clones tested. More importantly, there was a significant heating $\mathrm{x}$ clone interaction (Table 2, Fig. 1). Clones A-205 and 1582 starch digestibility changed little after being heated at $100 \mathrm{C}$ for $30 \mathrm{~min}$. Clone A-18 is more sensitive to heating; its digestibility improved by $14.7 \%$. The most significant change was demonstrated by clone A- 144, which increased its digestibility $37.8 \%$. However, this digestibility is below the digestibility of corn starch. In general, the slow response of sweetpotato starch digestibility to dry heat and the clone $\mathrm{x}$ heat interaction suggest that it is unlikely that sweetpotato starch digestibility can be improved by a simple heating method.

Both varieties with good and poor starch digestibility demonstrated a continuous response to pancreatin hydrolysis in a $16-\mathrm{h}$ digestion period, but the first $2 \mathrm{~h}$ of digestion was more effective than the seven successive 2-h intervals (Fig. 2). However, the difference in digestibility between these two genotypes was more obvious as digestion time increased. One can expect larger differences if digestibility is measured after $16 \mathrm{~h}$ of enzyme digestion. Those results, however, might not reflect the real situation in vivo, since a rat's hydrogen production rate, which partly indicates starch digestibility in vivo, reaches its maximum level $10 \mathrm{~h}$ after the rat feeds on sweetpotato (Tsou and Yang, 1984).

The correlation coefficient for the weight-

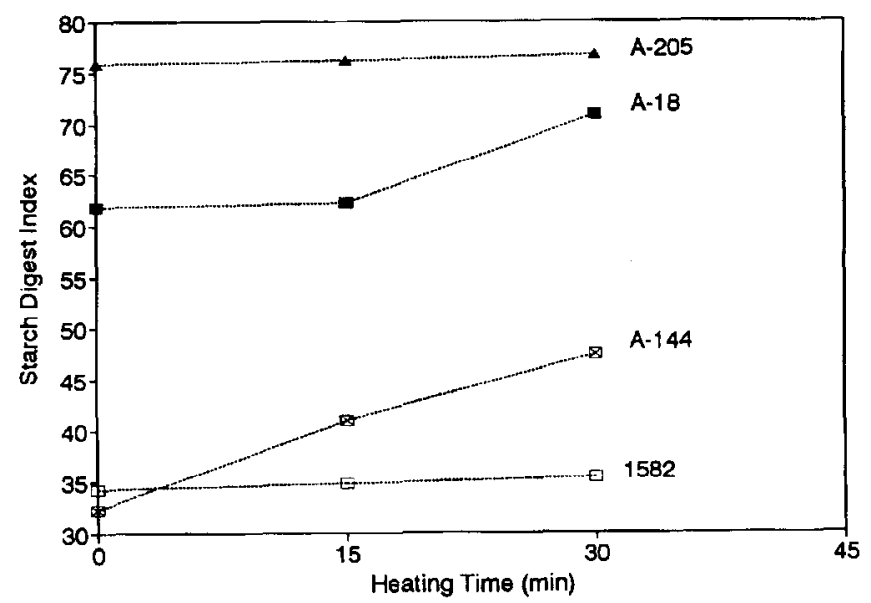

Fig. 1. Effect of dry heat on starch digestibility of four sweetpotato clones.

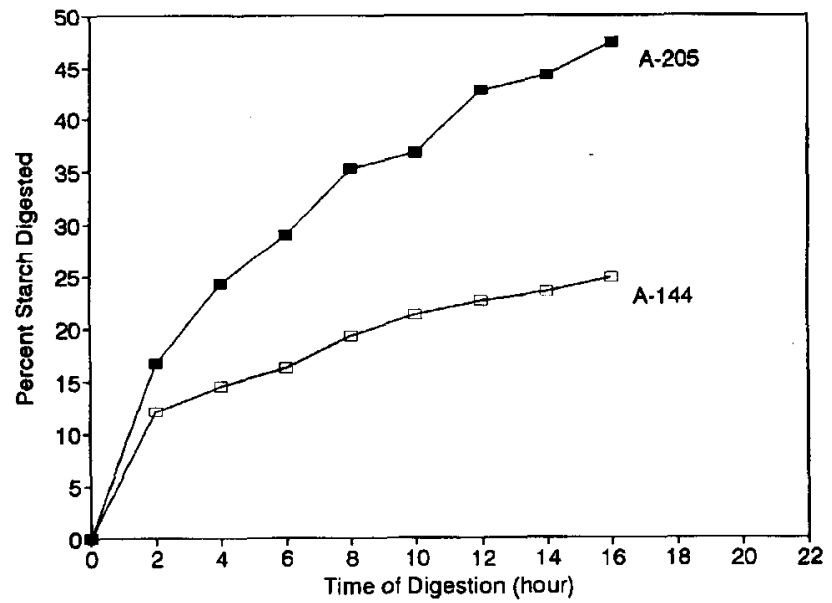

Fig. 2. Relationship between digestion time and raw sweetpotato starch digestibility of two clones.

loss (starch) and phenol-sulfuric acid (flour) methods (Table 2) was $r=0.875(\mathrm{n}=24, P<$ 0.05). The weight-loss method is simple, convenient, and reliable. It can be used as a screenmg method to handle many samples in a breeding program. An advantage of this method over the yeast fermentation methods used in previous sweetpotato studies is that uncontrollable error due to yeast variability is avoided. It is also convenient for mass screening. A disadvantage of the method is that, during hydrolysis, the end product remains in the reaction mixture and may have a feedback effect on hydrolysis, especially for those clones with digestible starch. If this is the case, differences may be underestimated.

\section{Literature Cited}

Dreher, M.L., C.J. Dreher, and J.W. Berry. 1984 Starch digestibility of foods: A nutritional perspective. CRC Critical Rev. Food Sci. Nutr. 20:47.

Gates, R.L. and R.M. Sandstedt. 1953. A method of determining enzymatic digestion of raw starch Cereal Chem. 30:413-419.

Hodge, J.E. and B.T. Hofreiter. 1972. Determination of the reducing sugars and carbohydrate, $\mathrm{p}$. 380. In: R.L. Whistler and M.L. Wolfrom (eds.). Methods in carbohydrate chemistry. vol. 1. Academic, New York.
Lu, S.Y., Q.H. Xue, D.P. Zhang, and B.F. Song. 1989. Sweet potato production, utilization and research in China, p. 21-30. In: Improvement of sweetpotato (Ipomoea batatas) in Asia. Rpt. Wkshp. Sweetpotato Improvement Asia, India Council Agr. Res., 24-28 Oct. 1988. Intl. Potato Center, Lima, Peru.

Tsou, S.C.S. and T.L. Hong. 1989. Digestibility of sweet potato starch, p. 127-136. In: Improvement of sweetpotato (Ipomoea batatas) in Asia. Rpt. Wkshp. Sweetpotato Improvement Asia, India Council Agr. Res., 24-28 Oct. 1988. Intl. Potato Center, Lima, Peru.

Tsou, S.C.S. and M.H. Yang. 1984. Flatulence factors in sweet potato. Acta Hort. 163:179-186.

Wilson, L.G., C.W. Averre, J.V. Baird, E.A. Estes, K.A. Sorensen, E.0. Beasley, and W.A. Skroch. 1980. Growing and marketing quality sweet potatoes. North Carolina State Univ. Ext. Serv., Raleigh. Publ. AG-09.

Woolfe, J.A. 1992. Sweetpotato, an untapped food resource. Cambridge Univ. Press, England.

Yeh, T.P. and J.C. Bouwkamp. 1985. Roots and vines as animal feed, p. 235-253. In: J.C. Bouwkamp (ed.). Sweet potato products: A natural resource for the tropics. CRC Press, Boca Raton, Fla.

Yeh, T.P., S.C. Wung, H.K. Lin, and C.C. Kuo. 1978. Studies on different methods of processmg some local feed materials to enhance their nutritive values for swine. Annu. Res. Rpt. Animal Ind. Res. Inst., Taiwan Sugar Corp. p. 2531. 